\title{
周方向縮約法を用いた円筒シェル構造物のモード特性同定
}

\author{
北原 篤 ${ }^{* 1}$ ，吉村 卓也 ${ }^{* 2}$
}

\section{Modal identification of cylindrical shell using circumference reduction method}

\author{
Atsushi KITAHARA $^{* 1}$ and Takuya YOSHIMURA ${ }^{* 2}$ \\ ${ }^{*}{ }_{1,{ }_{2}}$ Department of Mechanical Engineering, Tokyo Metropolitan University \\ 1-1 Minami-osawa, Hachioji-shi, Tokyo 192-0397, Japan
}

\section{Received 14 September 2014}

\begin{abstract}
For precision improvement of the noise prediction, the dynamic characteristics of structures need to be verified. This paper focuses on modal identification of the cylindrical shell structures. In such structures, vibration modes with complicated shapes exist densely. And structures made of composite material have high damping characteristics. Therefore, the experimental modal parameter extraction is somewhat difficult task. In this study, we investigate modal parameter identification method which is able to be applied to such structures. We propose circumference reduction method based on basis function, and non-linear least squares approach of curve-fitting. The circumference reduction method has an effect of reduction of modal density, so the difficulty of identification is improved. Using a simple cylindrical shell structure, the results of proposed method and FEM modal analysis are compared and evaluated. Furthermore, as an example of a real structure, the modal property of an automobile tire is identified. It is verified that the modal property of cylindrical shell structure can be identified effectively using proposed method.
\end{abstract}

Key words : Modal analysis, Modal parameter, Experimental modal analysis, Non-proportionally damping

\section{1. 緒言}

機械装置の振動騒音改良のためには，振動特性を把握した上での対策が重要であり，モード解析が広く用いら れている (城戸，2010). 更に，円筒シェル構造物のモード特性同定は，自動車タイヤ (Sandberg and Ejsmont, 2002) や航空機の機体 (Efimtsov and Lazarev, 2011) の振動騒音改良に必要な技術である. 近年，検討には FEM が利用さ れているが，FEM 予測精度の向上には，加振実験によりモデルの検証を行うことが重要である. 円筒シェル構造 物では，周方向と軸方向の曲げ振動が連成するため，モード形状が複雑になり，モード密度も高い(Fahy and Gardonio, 2007). また，構造物がゴムや樹脂を含む複合材料から成る場合，高分子に起因した高減衰特性を示す. これらの理由より，共振峰は明確になりにくく，特に中周波〜高周波では固有周波数が不明瞭となり，モード特 性同定の難易度が高い。それ故，FEM モデルの検証が困難となっている.

例えばタイヤの場合，モード特性同定の研究として，タイヤトレッド部の周方向の曲げ振動のみに着目して空 間フーリエ変換を利用したもの (松岡他, 2002) や, 拘束条件の違いを比較したもの (松原他, 2012) 等があるが, モード密度が比較的低く共振峰が捉えやすい低周波を対象としている． $300 \mathrm{~Hz}$ 以上の中周波帯域になると，タイ ヤが軸方向にも弾性変形するモードの出現によりモード密度が上昇し (Vercammen, et al., 2012), 同定の難易度が 上がる．放射音の観点では，このような中周波帯域におけるモードの把握が重要 (Waki, et al., 2011) であるが, 実験同定の手法は未だ提案されていない.

そこで本研究では，比較的減衰の大きな構造物のモード密度が高い周波数帯域においてモード特性同定を可能 にする，同定手法を提案することを目的とする，基底関数を定義可能な，円筒シェル構造物を対象とする，フー

\footnotetext{
No.14-00461 [DOI: 10.1299/transjsme.14-00461], J-STAGE Advance Publication date : 5 January, 2015

*1 正員，首都大学東京 大学院理工学研究科（干192-0397 東京都八王子市南大沢 1-1)

*2 正員, フェロー, 首都大学東京 大学院理工学研究科

E-mail of corresponding author: kitahara-atsushi@ed.tmu.ac.jp
} 
リエ級数を基底関数に用いて, 計測した周波数応答関数(FRF)を周方向の空間フーリエ級数に変換すると, 固有モ ードが周方向次数ごとに分離される．この変換により，モード密度が低下してカーブフィットの難易度が改善さ れると共に, 周方向次数を適当な次数で打ち切れば, 自由度縮約の効果がある. また, 周方向変形に対する重根 や，固有值が接近したモードも含めて，動特性を精度よく捉えるために，多点加振の FRF を同時に参照してモー ド特性を同定する多点参照を用いる. フーリエ級数に変換された FRFに対して, 多点偏分法 (吉村, 長松, 1990) を用いて同定を行う．多点偏分法は，非線形最小二乗法による最適化を利用した同定法である.

尚，円筒シェル構造物の軸方向に対しても，基底関数を定義することも考えられる．しかし，自動車タイヤな どの実構造物では, 周方向に比べて軸方向の周期対称性を仮定することは難しいため, 本研究では周方向のみを 基底関数で表現することとする.

本論文ではまず，提案する手法を説明し，数值シミュレーションにより，提案手法の妥当性検証を行う。一般 粘性減衰系の円筒シェル構造物を解析対象に用い, FEM で計算したモード特性を真值とする. 同モデルについて, FEM の定常応答解析で求めた FRFに, ランダム誤差を混入する. そして, 周方向縮約法と多点偏分法を用いて, モード特性の同定を行う. 同定結果を, FEMによるモード解析の真值と比較することにより, 提案手法の妥当性 を検証する.

次に，実構造物の例として自動車タイヤを取り上げ，提案手法により中周波帯域のモード特性同定を行い，手 法の有効性を評価する，更に，同タイヤについて，騷音低減の対策検討への応用を想定し，同定したモード特性 を利用した放射音への寄与度評価の可能性について考察を行う。

\section{2. モード特性同定法の提案}

\section{$2 \cdot 1$ 周方向縮約法}

FRF の応答点を, 図 1 に示すように, 円筒シェル上に配置された複数本の仮想リングの上に設定する. 各リン グの応答は,調和関数を用いた基底関数を用いて表現できることから,これを利用した周方向縮約法を提案する.

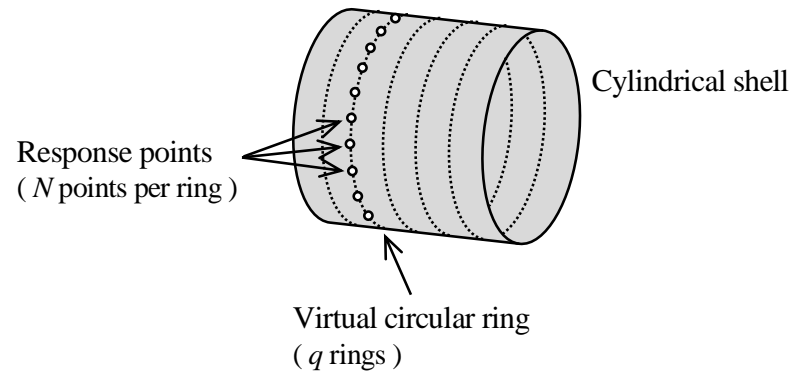

Fig. 1 Response points on virtual circular rings. The vibration response of each virtual ring can be expressed using superposition of harmonic functions.

\section{$2 \cdot 1 \cdot 1$ フーリエ級数の離散化}

周期が $T$ である任意の周期関数 $x(t)$ のフリエ級数展開は次式で表される. ただし $\omega=2 \pi / T$ は角周波数である.

$$
\begin{aligned}
& x(t)=\frac{a_{0}}{2}+\sum_{i=1}^{\infty}\left(a_{i} \cos i \omega t+b_{i} \sin i \omega t\right) \\
& a_{i}=\frac{2}{T} \int_{-T / 2}^{T / 2} x(t) \cos i \omega t d t \\
& b_{i}=\frac{2}{T} \int_{-T / 2}^{T / 2} x(t) \sin i \omega t d t
\end{aligned}
$$

ここで, 対象とする周期関数が離散值で与えられ， 1 周期が $x=\left\{x_{1}, x_{2}, \cdots, x_{N}\right\}$ である場合, 式(1), (2)は次のよ うな離散形で表現できる. ただし， $N$ は 1 周期に含まれる離散值の個数である. 


$$
\begin{aligned}
& x_{n}=\frac{a_{0}}{2}+\sum_{i=1}^{N / 2-1}\left[a_{i} \cos \left(i \frac{2 \pi n}{N}\right)+b_{i} \sin \left(i \frac{2 \pi n}{N}\right)\right]+\frac{a_{N / 2}}{2} \cos (\pi n) \quad(n=1,2, \cdots, N) \\
& a_{i}=\frac{2}{N} \sum_{n=1}^{N} x_{n} \cos \left(i \frac{2 \pi n}{N}\right) \quad(i=0,1, \cdots, N / 2) \\
& b_{i}=\frac{2}{N} \sum_{n=1}^{N} x_{n} \sin \left(i \frac{2 \pi n}{N}\right) \quad(i=1,2, \cdots, N / 2-1)
\end{aligned}
$$

\section{$2 \cdot 1 \cdot 2 \mathrm{FRF}$ 行列の周方向縮約}

加振点は円筒シェル上に任意に置かれた $p$ 個の点とする. 応答点は, 円筒シェル上に $q$ 本の仮想リングを設定 して, 各リング上に等間隔に $N$ 点配置し, 合計 $q N$ 点とする. 仮想リング上の応答点間隔は周方向角度で $2 \pi / N て ゙$

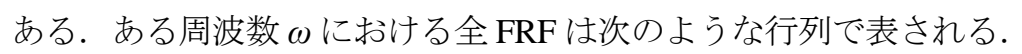

$$
\begin{aligned}
\mathbf{G}(\omega) & =\left[\begin{array}{c}
\mathbf{G}_{1}(\omega) \\
\mathbf{G}_{2}(\omega) \\
\vdots \\
\mathbf{G}_{N}(\omega)
\end{array}\right] \\
\mathbf{G}_{n}(\omega) & =\left[\begin{array}{ccc}
G_{n, 11}(\omega) & \cdots & G_{n, 1 p}(\omega) \\
\vdots & \ddots & \vdots \\
G_{n, q 1}(\omega) & \cdots & G_{n, q p}(\omega)
\end{array}\right]
\end{aligned}
$$

ただし, $\mathbf{G}(\omega)$ は全 FRF 行列, $\mathbf{G}_{n}(\omega)$ は各仮想リング上の第 $n$ 点のみで構成された FRF 行列, $G_{n, \beta a}(\omega)$ は $\mathbf{G}_{n}(\omega)$ のう ち $\alpha$ 点参照 $\beta$ 点応答の成分を表す.

この $n$ 系列の FRF について, 加振点ごと, 仮想リングごとに, 周方向にフーリエ級数展開すると, 次のように 級数展開された FRF が得られる.

$$
\begin{aligned}
& \mathbf{G}_{n}(\omega)=\frac{\mathbf{A}_{0}(\omega)}{2}+\sum_{i=1}^{N / 2-1}\left[\mathbf{A}_{i}(\omega) \cos \left(i \frac{2 \pi n}{N}\right)+\mathbf{B}_{i}(\omega) \sin \left(i \frac{2 \pi n}{N}\right)\right]+\frac{\mathbf{A}_{N / 2}}{2} \cos (\pi n) \\
& \mathbf{A}_{i}(\omega)=\frac{2}{N} \sum_{n=1}^{N} \mathbf{G}_{n}(\omega) \cos \left(i \frac{2 \pi n}{N}\right) \\
& \mathbf{B}_{i}(\omega)=\frac{2}{N} \sum_{n=1}^{N} \mathbf{G}_{n}(\omega) \sin \left(i \frac{2 \pi n}{N}\right)
\end{aligned}
$$

ここでは，仮想リングの円環振動を，三角関数を基底関数として表しているが，これは円筒シェルの周方向曲げ 振動の固有モードに対応する (Fahy and Gardonio, 2007). すなわち $i$ は, モード次数に相当するものである. 振動 モードの例を図 2 に示寸.
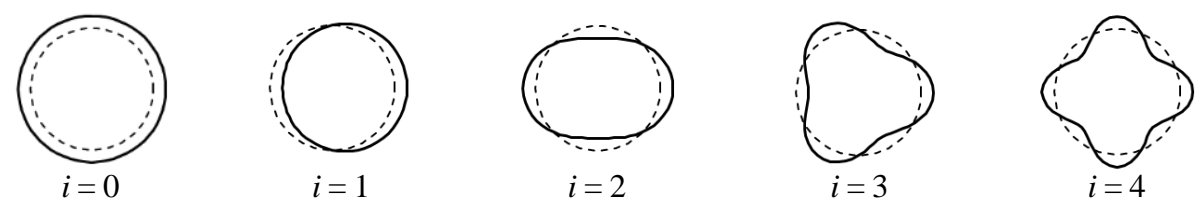

Fig. 2 Examples of ring mode shape. The order of the Fourier series corresponds to the order of these mode shape.

式(7)および(8)は，各 $i$ の成分を重ね合せた形となっており，式(7)のうち一つの $i$ 成分を取り出した次式を用いれ ば，周方向 $i$ 次の振動モードの成分が抽出される.

$\mathbf{G}_{n}{ }^{(i)}(\omega)=\mathbf{A}_{i}(\omega) \cos \left(i \frac{2 \pi n}{N}\right)+\mathbf{B}_{i}(\omega) \sin \left(i \frac{2 \pi n}{N}\right)$ 
この時, $N p q$ の自由度を有していた $\mathbf{G}(\omega)$ は，それぞれ $p q$ の自由度を有する $\mathbf{A}_{i}(\omega)$ と $\mathbf{B}_{i}(\omega)$ に縮約されたことに なる. 自由度は $2 / N$ 倍に縮約された. また, 周方向の振動モードは $i$ 次のみが抽出されており, 軸方向次数の異 なるモードのみが各固有モードとして存在している状態であるため, モード密度は大幅に低減されている，した がって，級数展開された FRFである

$$
\mathbf{H}_{i}(\omega)=\left[\begin{array}{l}
\mathbf{A}_{i}(\omega) \\
\mathbf{B}_{i}(\omega)
\end{array}\right]
$$

を用いてモード特性同定することで，自由度が圧縮かつモード密度が低減された状態でのモード特性同定を行う ことになり，同定精度の向上および効率化が見込まれる．また，同定されたモード形は級数であるので，式(9)を 用いて復元することで元の円筒シェルの全応答点情報を含むモード形が得られる．このモード特性同定を，所望 の周方向次数についてそれぞれ行う.

以上の手法を，本論文では，モード特性同定における周方向縮約法として提案する.

\section{$2 \cdot 2$ 多点偏分法}

本研究では, 一般粘性減衰系を仮定し, 多点偏分法(吉村, 長松, 1990)を用いてモード特性同定を行う。一般 粘性減衰系の FRF は次式で表わされる.

$$
\mathbf{G}(\omega)=\sum_{r=1}^{N}\left[\frac{\phi_{r} \xi_{r}{ }^{T}}{\sigma_{r}+j\left(\omega-\omega_{\mathrm{d} r}\right)}+\frac{\phi_{r}{ }^{*} \xi_{r}{ }^{* T}}{\sigma_{r}+j\left(\omega+\omega_{\mathrm{d} r}\right)}\right]
$$

ここで， $\omega_{\mathrm{d} r}$ は減衰固有角振動数， $\sigma_{r}$ はモード減衰率， $\phi_{r}$ は固有モードベクトル， $\xi_{r}$ はモード寄与率ベクトルであ る. *は複素共役を表す.

対象周波数範囲を限定し, $n$ 個の固有モードのみを採用した場合の FRF は次式となる.

$$
\mathbf{G}(\omega)=\sum_{r=1}^{n}\left[\frac{\boldsymbol{\phi}_{r} \boldsymbol{\xi}_{r}{ }^{T}}{\sigma_{r}+j\left(\omega-\omega_{\mathrm{d} r}\right)}+\frac{\boldsymbol{\phi}_{r}{ }^{*} \boldsymbol{\xi}_{r}{ }^{* T}}{\sigma_{r}+j\left(\omega+\omega_{\mathrm{d} r}\right)}\right]+\frac{\mathbf{C}}{\omega^{2}}+\mathbf{D}
$$

ここで, $n$ は対象とする周波数範囲に含まれる固有值の数である. $\mathbf{C}$ および $\mathbf{D}$ は対象周波数範囲の外に存在する 固有值の影響を表すための剰余項であり, $\mathbf{C} / \omega^{2}$ は低次固有モードをまとめて剛体モードで近似したもの, $\mathbf{D} は$ 高 次モードの影響をまとめて岡性で近似したものである。多点偏分法においては, 一般粘性減衰系を仮定し, FRF の理論式として式(12)を用いて，ガウスニュートン法に基づきモード特性を求める.

多点偏分法では反復計算によりモード特性を求めるが, 式(12)の未知パラメータのうち非線形項の初期值が必 要である. 初期值は, 多点参照に対応したモード指示関数である MMIF (Williams, et al., 1985) や, 複素モード指 示関数 CMIF (Shih, et al., 1989) を用いて求められる. 求めた初期值に基づき, 多点参照に対応した多点偏分法を 用いてモード特性を同定する.

本研究では，まず，円筒シェルの周方向次数ごとに，周方向縮約された FRF を作成する．次に，非線形項の初 期值を与えた上で, 多点偏分法を用いてモード特性を同定する. FRF は各周方向次数成分に分解されるため, モ 一ド特性同定は, 周方向次数に縮約された FRFに対して独立に行えばよく, 処理を軽減できる. 例えば加振点が $p$ 個, 仮想リングが $q$ 本であれば, 任意の周方向次数について, $p$ 点参照, $2 \times q$ 点応答として同定を行える. 尚, 初期值の設定には，一般粘性減衰系におけるモード特性の推定に優れる CMIF を用いる.

\section{3. 有限要素モデルを用いた検証}

\section{$3 \cdot 1$ 解析対称の円筒シェルモデル}

本章では, 図 3 に示寸, 有限要素でモデル化された円筒シェルモデルを用いて, 提案手法の検証を行う. FRF の算出と，モード特性の真值の算出には，商用ソフトウエアの ABAQUS (Dassault Systèmes Simulia, 2011) を用い る. シェルは炭素鋼で, 一部の領域に $\mathbf{C}=\beta \mathbf{K}$ で表わされる比例粘性減衰を定義し, 他の領域は不減衰としている. 従って，構造物全体では非比例粘性減衰系である．円筒の両端を単純支持する. 
提案する手法を用いてモード特性を同定するために, FEM で 3 点参照の条件で FRF を算出する. 加振点を図 3 にO印で示す．応答点は FEM モデルの 680 節点のうち，等間隔に分布させた 160 点を用いる. 加振方向は円筒 表面の面直方向とし，応答の測定も面直方向を用いる．合計 480 個の FRF が取得される.

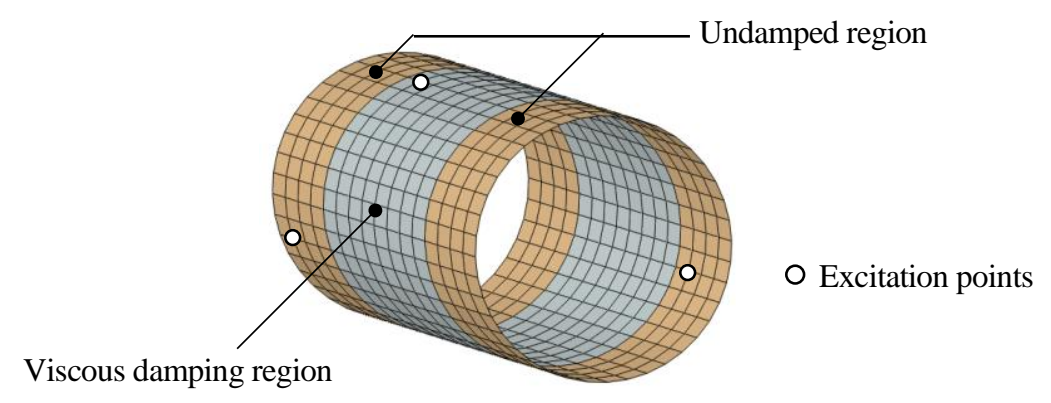

Fig. 3 A cylindrical shell FE model. Both edges of the cylinder are simply supported. This model has viscous damping region and undamped region. So it is non-proportional viscous damping condition.

\section{$3 \cdot 2$ 誤差混入とモード特性同定}

取得した FRF に対して，式(13)のように，ランダム誤差を混入する.

$$
G^{\prime}(\omega)=G(\omega)+\operatorname{Re}[G(\omega)] a_{\text {error }} \varepsilon_{r}(\omega)+j \operatorname{Im}[G(\omega)] a_{\text {error }} \varepsilon_{i}(\omega)
$$

$a_{\text {error }}$ は誤差係数を表し，本解析では $a_{\text {error }}=0.03$ とする． $\varepsilon_{r}(\omega), \varepsilon_{i}(\omega)$ はいずれも，標準偏差が 1 の正規分布に従 う乱数である. つまり, 混入誤差の根二乗平均を, 元の FRF の $3 \%$ に設定する.

FRF の応答点は，円筒シェル上に 8 本の仮想リングを構成する. 特定の周方向次数に着目し，加振点毎，リン グ毎に FRF がフーリエ級数に変換される.この周方向縮約された FRF に対して, 多点偏分法を用いてモード特 性同定を行う。

\section{$3 \cdot 3$ 周方向縮約の結果}

図 4 に，ランダム誤差を混入させたアクセレランス FRF の例を緑線で，その応答点を含む仮想リングの 2 次の フーリエ級数成分を青線で，それぞれ示す．元の FRF とフーリエ級数 FRF との差は，他の次数成分の寄与を意 味する.それは周方向 2 次のモードを同定する上では不要な成分である.このフーリエ級数による周方向縮約は, 加振点毎, 仮想リング毎に行われる. 加振点数は 3 点, 仮想リングは 8 本であり, フーリエ級数は式(8)のように $2 つ て ゙ 1$ 組であるので, 一つの周次数に対して, モード同定に用いる縮約 FRF として 48 個の FRF が作成される.
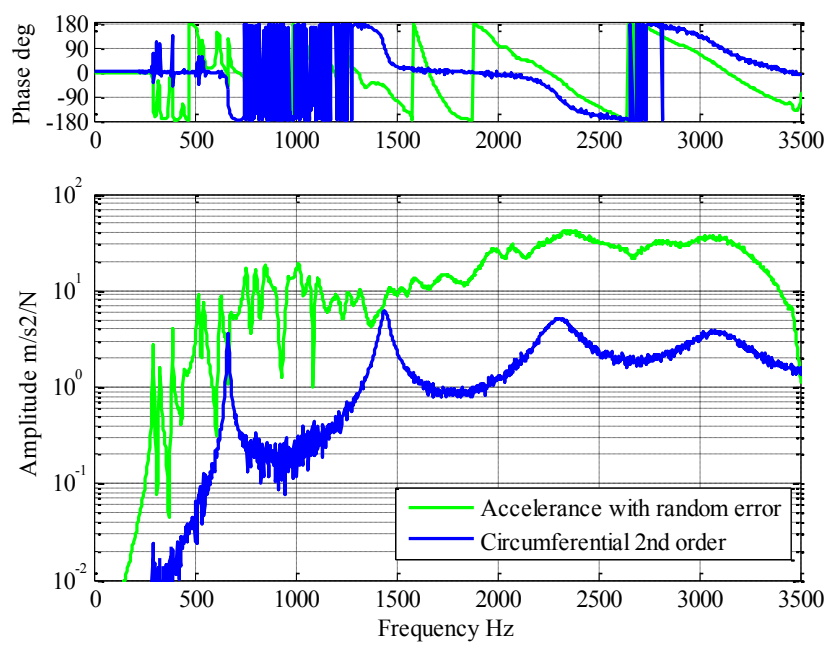

Fig. 4 An example of accelerance FRF. The green line is FRF with random error. The blue line is the 2nd order Fourier series component. The difference between green line and blue line denotes unnecessary component for the modal identification of circumferential 2nd order mode. 


\section{$3 \cdot 4$ モード特性同定結果}

各周方向次数を対象としながら，48 個の FRF を用いて多点偏分法によりモード特性同定を行う. 初期值決定 に用いる CMIF の算出例として, 周 2 次の結果を図 5 に示寸. 各共振における重根の存在が検出されている. こ れを用いて初期值を決定し, 多点偏分法によりモード特性同定を行う. 式(12)で表現される合成 FRF と, 元の FRF とを比較寸ることによって，カーブフィットの良悪を評価できる．図 6 にカーブフィットの例を示す．ランダム 誤差が存在する状態においても，精度よくカーブフィットできていることが確認できる.

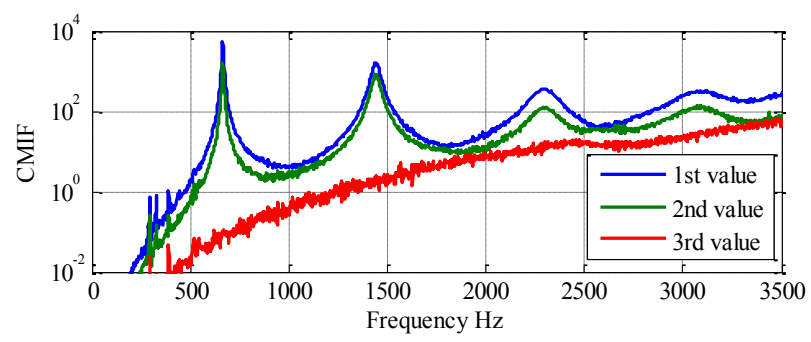

Fig. 5 An example of CMIF value. Existence of repeated roots at each resonance can be detected. The initial value is determined using this result.
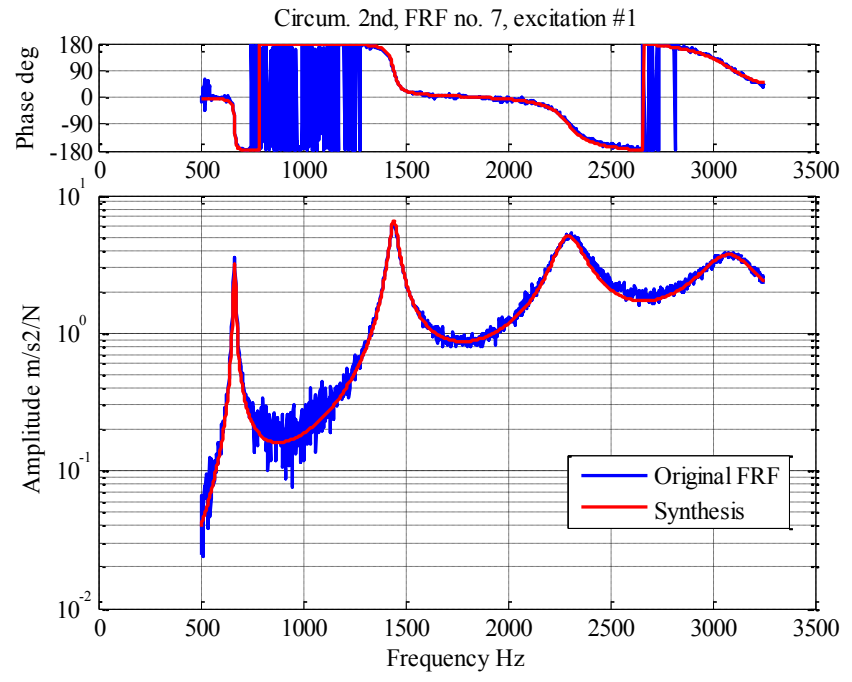

Fig. 6 An example of curve fitting results. The blue line is an original FRF and the red line is a synthesized FRF using identified modal properties. The curve fitting has been done with good accuracy.

$3000 \mathrm{~Hz}$ 以下，周方向次数 1 次〜 7 次における同定結果を表 1 に示寸. 同定されたモード形の例を図 7 に示寸. モードは重根も含めて漏れなく同定できている．固有周波数とモード形は精度よく同定できている．モード減衰 比は固有周波数に比べると同定誤差が大きいものの，概ねよく同定できている.

以上の結果より, モード密度が高く, また図 7 のようにモード減衰比 4\%程度という高減衰のモードを含み, 且つランダム誤差を含む条件においても，提案手法はモード特性を精度よく同定できることが検証できた。 
Kitahara and Yoshimura, Transactions of the JSME (in Japanese), Vol.81, No.822 (2015)

Table 1 Results of identification, below $3000 \mathrm{~Hz}$. The modes detected by FEM analysis are fully identified using the proposed method. Modal damping ratios are more affected by the FRF error.

\begin{tabular}{c|c|c|c|c|c|c}
\hline \multirow{2}{*}{$\begin{array}{c}\text { Circumrerential } \\
\text { order }\end{array}$} & \multicolumn{2}{|c|}{$\begin{array}{c}\text { Number of } \\
\text { modes }\end{array}$} & \multicolumn{2}{c|}{$\begin{array}{c}\text { Average of } \\
\text { identification error [\%] }\end{array}$} & \multicolumn{2}{c}{$\begin{array}{c}\text { Maximum of } \\
\text { identification error [\%] }\end{array}$} \\
\cline { 2 - 7 } & FEM & Identified & $f_{r}$ & $\zeta_{r}$ & $f_{r}$ & $\zeta_{r}$ \\
\hline 1 & 4 & 4 & 0.13 & 6.91 & 0.20 & 14.87 \\
\hline 2 & 6 & 6 & 0.12 & 6.71 & 0.36 & 13.49 \\
\hline 3 & 10 & 10 & 0.10 & 7.16 & 0.29 & 16.39 \\
\hline 4 & 12 & 12 & 0.07 & 4.42 & 0.34 & 12.16 \\
\hline 5 & 14 & 14 & 0.06 & 4.35 & 0.23 & 9.60 \\
\hline 6 & 16 & 16 & 0.07 & 3.03 & 0.34 & 17.66 \\
\hline 7 & 18 & 18 & 0.07 & 3.36 & 0.38 & 16.00 \\
\hline & & & \multicolumn{3}{c}{$f \cdot$ ramped natural frequency } \\
\hline
\end{tabular}

$f_{r}$ : damped natural frequency, $\zeta_{r}:$ modal damping ratio

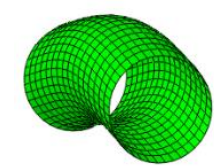

FEM: $f_{r}=1272 \mathrm{~Hz}, \zeta_{r}=0.94 \%$

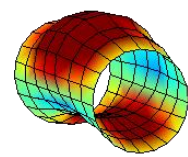

Identified: $f_{r}=1273 \mathrm{~Hz}, \zeta_{r}=0.91 \%$

(a) Circumferential 1st, axial 1st mode

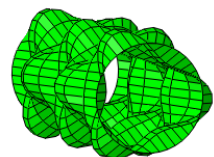

FEM: $f_{r}=2795 \mathrm{~Hz}, \zeta_{r}=4.00 \%$

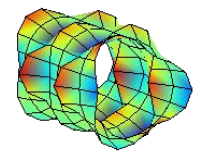

Identified: $f_{r}=2795 \mathrm{~Hz}, \zeta_{r}=4.00 \%$

(b) Circumferential 3rd, axial 5th mode
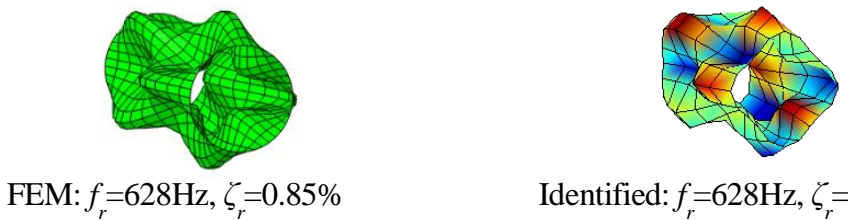

FEM: $f_{r}=628 \mathrm{~Hz}, \zeta_{r}=0.85 \%$

Identified: $f_{r}=628 \mathrm{~Hz}, \zeta_{r}=0.82 \%$

(c) Circumferential 4th, axial 2nd mode

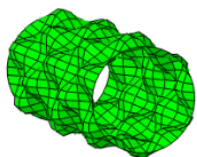

FEM: $f_{r}=1443 \mathrm{~Hz}, \zeta_{r}=2.12 \%$

Identified: $f_{r}=1443 \mathrm{~Hz}, \zeta_{r}=2.18 \%$

(d) Circumferential 6th, axial 5th mode

Fig. 7 Examples of mode shape. Mode shapes are identified with good accuracy. 


\section{4. 実構造物への適用例}

\section{$4 \cdot 1$ 加振実験}

提案手法の実構造物への適用例として，乗用車用タイヤを対象に加振実験とモード特性同定を行う。対象物を 図 8 に示す. 支持条件は，車両取付状態を再現し，ホイールのボルト部を固定している. 加振点は 15 点，応答点 は 18 本の仮想リング上に各 40 点の計 720 点を設定し，FRF 総数は 10800 個である．タイヤのトレッド部（中心 軸と平行な面）だけでなく，サイドウォール部（中心軸に垂直な面）も円筒シェルの一部とみなして，トレッド 部に加えサイドウォール部にも仮想リングを設定し，タイヤ表面全体を覆うように応答点を配置している．応答 の測定方向は各点における面直方向である.

この計測された FRF に対して，提案手法によりモード特性同定を行う。まず，周方向縮約法により FRF を各 周方向次数成分のフーリエ級数に変換すると, FRF 数は 540 個と $1 / 20$ に縮約される. この縮約 FRF を用いて, 多点偏分法によりモード特性同定を行う。

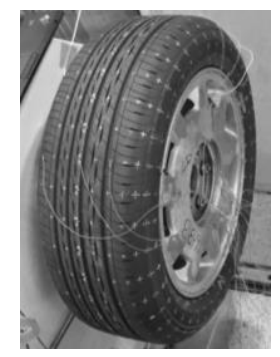

Fig. 8 An automobile tire used for vibration test. The modal properties of the tire are identified by the proposed method.

\section{$4 \cdot 2$ モ一ド特性同定結果}

計測された FRF の例を図 9 に示す。青線の計測 FRF を見ると，200Hz 以下は共振ピークが目立つのに対し， $200 \mathrm{~Hz}$ 以上ではモード密度が高く減衰も大きいため，ピークが目立っておらず，モード特性同定が難しい状態に ある. 一方，周 1 次に関する周方向縮約を行った赤線においては，不要なピークが除去されたことや，振幅低下 に表れているように不要な成分が除去されたことによって，モード密度の低減による同定難易度の改善が見込ま れる.
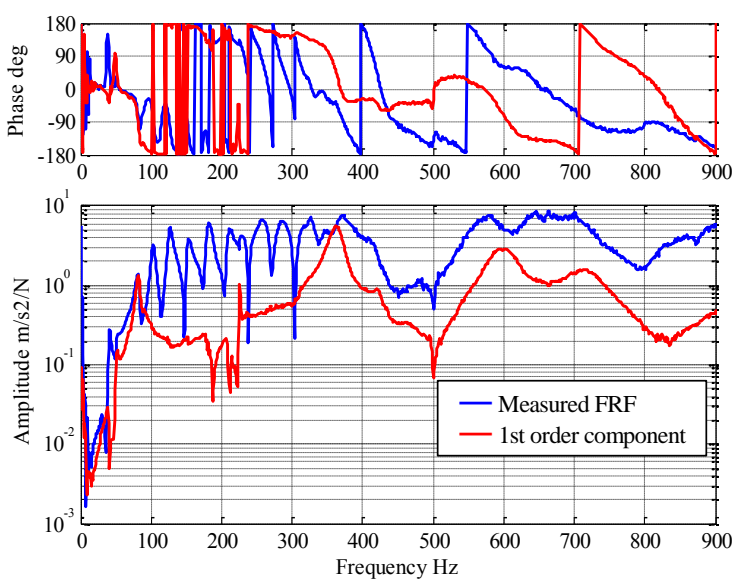

Fig. 9 An example of accelerance FRF. The blue line is the measured FRF. The red line is the 1st order Fourier series component. The reduction of amplitude denotes disappearance of unnecessary component. Because of reduction of modal density, the difficulty of identification seems improve.

この周 1 次の縮約 FRF における CMIF を図 10 に示す. 各線はそれぞれ第 1 〜第 15 特異值成分を表す。重根に 加えて近接モードも検出できており，初期值の決定が可能であることがわかる．例えば， $50 ， 80 ， 180 ， 230 \mathrm{~Hz}$ 


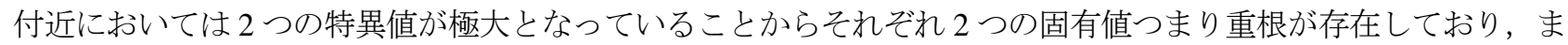
た $360 \mathrm{~Hz}$ 付近においては 4 つの特異值が極大のため, 4 固有值すなわち 2 組の重根が近接して存在していること を検出でき，初期值を定めることができる.

このように CMIF から定まる初期值を用いて，多点偏分法によりモード特性同定を行う．カーブフィット結果 の例を図 11 に示寸．まだ残差はあるものの，概ねよくカーフィットできていると言える.

なお， $600 \mathrm{~Hz}$ 付近のピークにおける残差の原因については，実際のタイヤは厚さ方向の影響で理想的なシェル とは見なせない点や，サイドウォール部が存在している点により，実際の固有モードが三角関数と完全には対応 していない可能性があり, その状況下で特定の周次数成分のみを抽出したため, 式(12)の理論 FRF で十分にカー ブフィットできなかったという事が推定される.

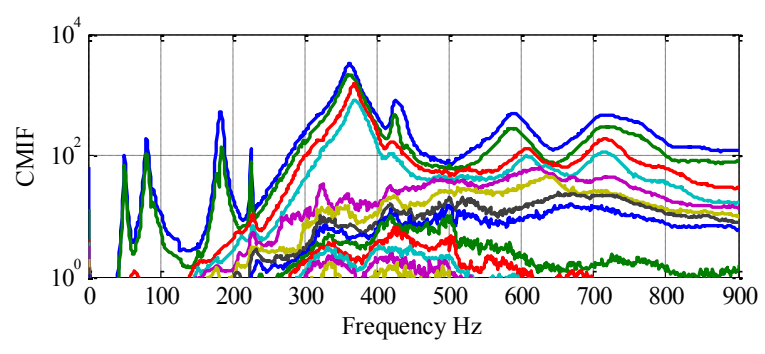

Fig. 10 An example of CIMF value. Each line shows singular value component. The multiple root and neighboring mode can be detected. Initial value can be determined from this result.
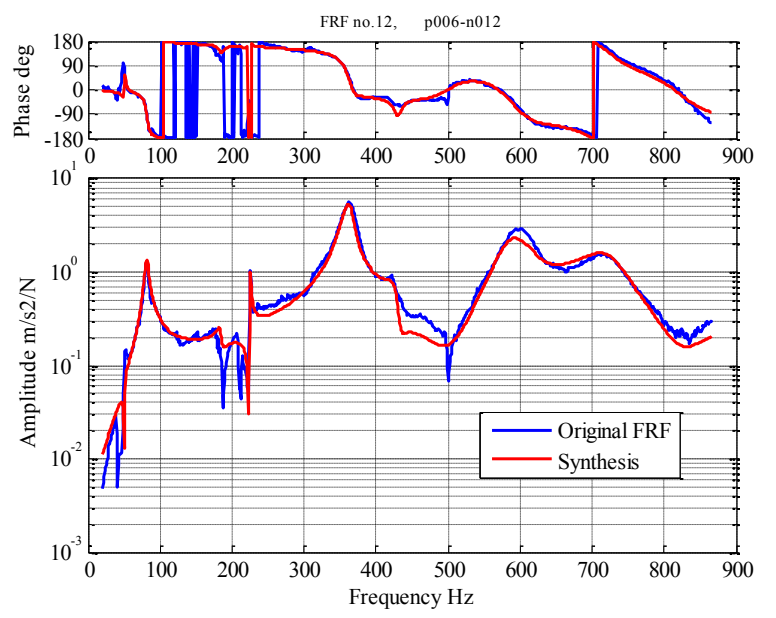

Fig. 11 An example of curve fitting result. The blue line is an original FRF and the red line is a synthesized FRF using identified modal properties. The curve fitting has been done with good accuracy.

周 1 次〜周 3 次について, 同定された固有值を表 2 に, また代表的なモード形を図 12 に示寸. 周 1 次〜周 3 次のモードだけを見ても固有值が接近しており，周 4 次以上についても同様に固有值の存在が推測されることか ら，実際のモード密度は更に高いことが推測される．モード減衰比についても4\%程度と大きい值である．この ようなモード特性同定が難しい条件においても，提案手法を用いることで，確実な同定を行うことができた，モ ード形に着目寸ると, 周方向の次数と軸方向の次数が組み合わされた, 円筒シェルモデルに類似のモード形が重 根も含め同定できており, 同定結果は信頼性が高いと推定される.

ここで, 軸方向の次数について補足する. タイヤの場合, 円筒シェルモデルとは異なり, 通常の面外曲げ変形 のモードの他に, 内部空気の共鳴モードや, ホイール弾性変形が主体でタイヤが従属するモードなども存在して いる. 従って, 軸方向のモード次数は, 腹・節の数と 1 対 1 で対応するものではない. 例えば, 周 1 次の No. 7 , 8 モードは, 内部空気の共鳴モードである. 空気の減衰はタイヤより小さいため, モード減衰比は他のモードの $1 / 10$ 程度となっている. 


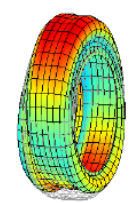

1-2 mode

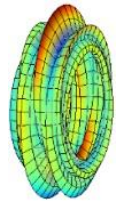

1-12 mode

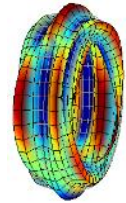

2-7 mode

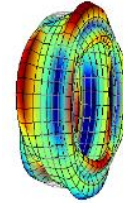

2-11 mode

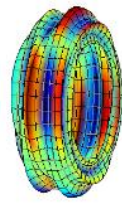

2-15mode

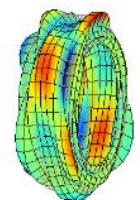

3-3 mode

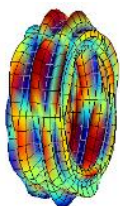

3-9 mode

Fig. 12 Examples of identified mode shapes. Here, ' $x$ - $y$ mode' denotes circumferential $x$-th and axial $y$-th order mode. The mode shapes which are similar to the cylindrical shell's mode shapes are identified.

Table 2 Identified modal property using proposed method. It can be seen that modal density is high and damping ratio is also high. Although it is such difficult condition, modal property is identified well.

(a) Circumferential 1st order modes

\begin{tabular}{c|c|c|c}
\hline No. & $f_{r}[\mathrm{~Hz}]$ & $\zeta_{r}[\%]$ & Axial order \\
\hline 1 & 50.7 & 2.96 & 1 \\
\hline 2 & 50.8 & 2.84 & $1^{*}$ \\
\hline 3 & 81.1 & 3.95 & 2 \\
\hline 4 & 81.3 & 4.14 & $2^{*}$ \\
\hline 5 & 183.4 & 1.35 & 3 \\
\hline 6 & 184.0 & 2.73 & $3^{*}$ \\
\hline 7 & 225.4 & 0.35 & 4 \\
\hline 8 & 225.5 & 0.32 & $4^{*}$ \\
\hline 9 & 360.9 & 2.61 & 5 \\
\hline 10 & 361.3 & 2.62 & $5^{*}$ \\
\hline 11 & 367.4 & 2.82 & 6 \\
\hline 12 & 368.5 & 2.33 & $6^{*}$ \\
\hline 13 & 423.3 & 2.56 & 7 \\
\hline 14 & 428.0 & 1.30 & $7^{*}$ \\
\hline 15 & 585.2 & 4.13 & 8 \\
\hline 16 & 586.5 & 4.31 & $8^{*}$ \\
\hline 17 & 609.9 & 6.07 & 9 \\
\hline 18 & 613.3 & 5.76 & $9^{*}$ \\
\hline 19 & 710.9 & 4.08 & 10 \\
\hline 20 & 711.7 & 3.66 & $10^{*}$ \\
\hline 21 & 716.8 & 3.79 & 11 \\
\hline 22 & 721.3 & 3.62 & $11^{*}$ \\
\hline 23 & 752.1 & 4.51 & 12 \\
\hline 24 & 763.3 & 5.62 & $12^{*}$ \\
\hline
\end{tabular}

(b) Circumferential 2nd order modes

\begin{tabular}{c|c|c|c}
\hline No. & $f_{r}[\mathrm{~Hz}]$ & $\zeta_{r}[\%]$ & Axial order \\
\hline 1 & 100.3 & 3.05 & 1 \\
\hline 2 & 100.4 & 3.07 & $1^{*}$ \\
\hline 3 & 102.7 & 2.64 & 2 \\
\hline 4 & 102.7 & 2.67 & $2^{*}$ \\
\hline 5 & 324.3 & 0.83 & 3 \\
\hline 6 & 324.6 & 0.80 & $3^{*}$ \\
\hline 7 & 378.5 & 2.33 & 4 \\
\hline 8 & 379.8 & 2.79 & $4^{*}$ \\
\hline 9 & 409.7 & 2.26 & 5 \\
\hline 10 & 410.8 & 2.14 & $5^{*}$ \\
\hline 11 & 602.3 & 3.66 & 6 \\
\hline 12 & 603.3 & 3.49 & $6^{*}$ \\
\hline 13 & 624.8 & 5.32 & 7 \\
\hline 14 & 629.6 & 5.47 & $7^{*}$ \\
\hline 15 & 712.1 & 3.30 & 8 \\
\hline 16 & 712.8 & 3.28 & $8^{*}$ \\
\hline 17 & 763.2 & 4.53 & 9 \\
\hline 18 & 765.8 & 3.97 & $9^{*}$ \\
\hline 19 & 794.9 & 4.71 & 10 \\
\hline 20 & 796.1 & 4.39 & $10^{*}$ \\
\hline & & & \\
\hline & & & \\
\hline & & & \\
\hline & & & \\
\hline & & &
\end{tabular}

$f_{r}:$ damped natural frequency, $\zeta_{r}:$ modal damping ratio

* denotes circumferential multiple root. (c) Circumferential 3rd order modes

\begin{tabular}{c|c|c|c}
\hline No. & $f_{r}[\mathrm{~Hz}]$ & $\zeta_{r}[\%]$ & Axial order \\
\hline 1 & 126.5 & 2.20 & 1 \\
\hline 2 & 126.7 & 2.22 & $1^{*}$ \\
\hline 3 & 150.8 & 3.56 & 2 \\
\hline 4 & 151.0 & 3.62 & $2^{*}$ \\
\hline 5 & 381.3 & 2.52 & 3 \\
\hline 6 & 382.8 & 2.51 & $3^{*}$ \\
\hline 7 & 416.5 & 2.64 & 4 \\
\hline 8 & 417.7 & 2.53 & $4^{*}$ \\
\hline 9 & 597.9 & 4.99 & 5 \\
\hline 10 & 601.9 & 4.89 & $5^{*}$ \\
\hline 11 & 636.9 & 4.57 & 6 \\
\hline 12 & 640.3 & 3.82 & $6^{*}$ \\
\hline 13 & 690.2 & 2.89 & 7 \\
\hline 14 & 692.2 & 2.65 & $7^{*}$ \\
\hline 15 & 729.8 & 2.68 & 8 \\
\hline 16 & 731.8 & 2.79 & $8^{*}$ \\
\hline 17 & 773.1 & 3.83 & 9 \\
\hline 18 & 778.3 & 3.17 & $9^{*}$ \\
\hline 19 & 837.3 & 7.65 & 10 \\
\hline 20 & 848.3 & 6.83 & 11 \\
\hline 21 & 848.4 & 4.97 & $11^{*}$ \\
\hline 22 & 863.3 & 5.06 & $10^{*}$ \\
\hline & & & \\
\hline & & & \\
\hline
\end{tabular}




$$
\frac{p_{O}}{F_{S}}=-\frac{v_{S}}{Q_{O}}
$$

この考え方を利用すると，音響加振時の FRF に対して，前節で同定されたモード特性を用いてモード寄与率を パラメータとしてカーブフィットすることにより，放射音における各モードの寄与を算出することができる，す なわち, タイヤの加振試験によって得られたモード特性の内, $\sigma_{r}, \omega_{\mathrm{d} r}, \boldsymbol{\phi}_{r}$ を既知, $\boldsymbol{\xi}_{r}$ および $\mathbf{C}, \mathbf{D}$ を未知として, 最小二乗法により式(12)を構成する未知パラメータを決定することができる.

\section{$4 \cdot 4$ 放射音への寄与の評価結果}

音響加振時の加速度応答の計測は, 図 1 と同様に仮想リング上に配置した応答点で行い, 得られた FRF を各周 次数に分離する. そして, 周次数ごとに前述の通り同定されたモード特性を用いてカーブフィットし，モード寄 与率を算出する。なお，放射音の観測点はタイヤ表面から $0.5 \mathrm{~m}$ の位置に設定し，音源には SIEMENS 社の体積速 度加振器 LMS Q-MHF を用いる. 図 13 は, 音響加振の精度検証のため, 音響加振-加速度応答の FRF（破線）と, ハンマリング加振-音圧応答の FRF（実線）の比較を行ったものである．放射音の相反性定理に則り，両者が概祆 一致していることから，音響加振実験は十分な精度を有すると判断する.
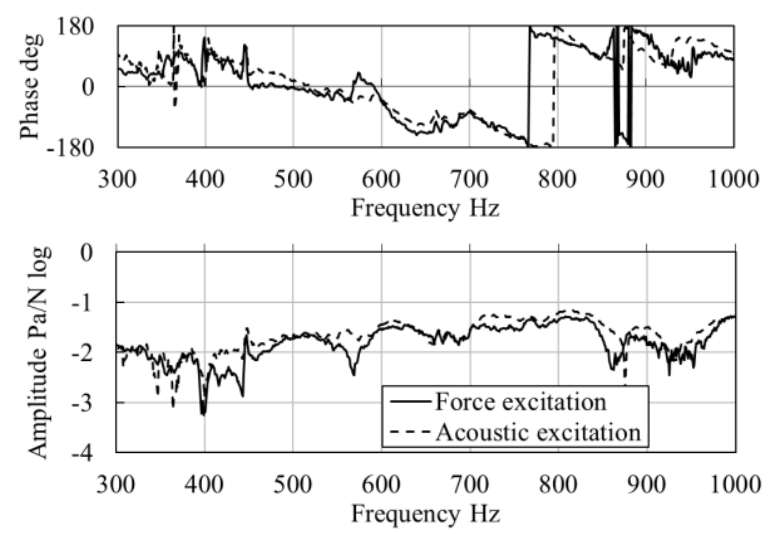

Fig. 13 Comparison of directly and reciprocally measured FRFs. The results are nearly equivalent. The acoustic excitation test has sufficient accuracy.

周 1 次, 2 次, 3 次成分について, 放射音への寄与の評価結果を図 14 に示寸．青線が音響加振時の加速度応答 を表す測定 FRF である．同定したモード特性を用いてカーブフィットを行った結果を赤線で，その時のモード毎 の寄与を破線でそれぞれ示寸，青線と赤線を比較すると，誤差はあるものの，ピークは概ね捉えられていると言 える. そのピークに寄与しているモードを見ることで, 例えば周 1 次成分については, $600 \mathrm{~Hz}$ のピークは No.15 モード, $700 \mathrm{~Hz}$ のピークはNo.22 モードの寄与がそれぞれ大きいことが理解できる. 尚, No. 15 およびNo. 22 の モードは，近い周波数帯域に存在する他のモードに比べ，軸方向の節の数が少ないモード形となっており，放射 音への寄与が大きいのは妥当であると考えられる.

以上より，モード特性同定の結果を用い，音響加振時の加速度応答の FRF に対してモード寄与率を決定するこ とにより，放射音低減に寄与するモードを特定できることを示した。 


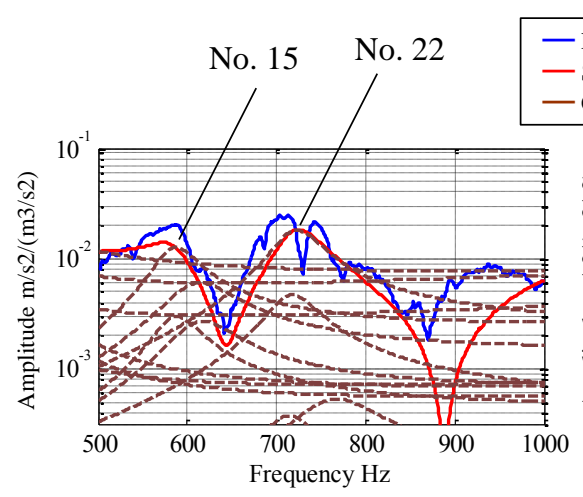

(a) Circumferential $1 \mathrm{st}$

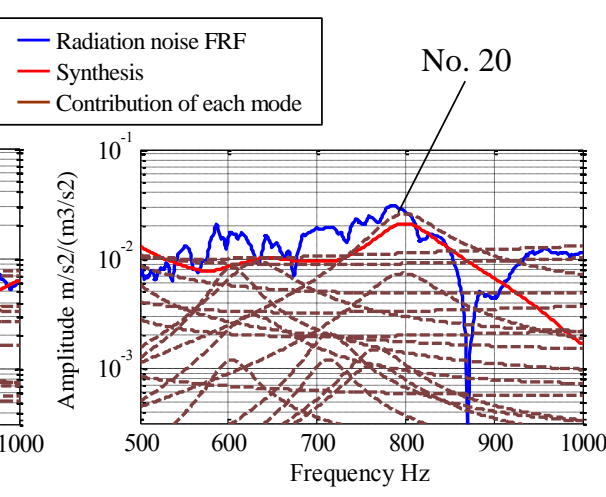

(b) Circumferential 2nd

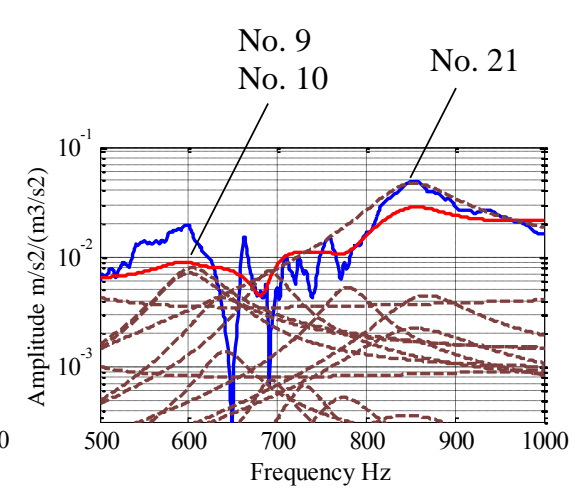

(c) Circumferential 3rd

Fig. 14 Measured radiation noise using volume source and the result of curve-fitting using identified modal property. The modes which contribute to the radiation noise can be estimated.

\section{5. 結言}

本研究では，モード密度の高さや共振峰の鈍さからモード特性同定の難易度が高い，高減衰の円筒シェル構造 物を対象に，新たなモード特性同定の手法を提案した。また，提案手法を FEM モデルおよび実構造物に適用し， その有効性を検討した。得られた結論を以下に示す.

1) 円筒シェル構造物において, 周方向の振動モードは調和関数（正弦波および余弦波）を基底関数として表現 できる．これに基づき，周方向の空間フーリエ級数を用いて FRF 縮約することで，特定の周方向次数の成分の みを抽出し, モード特性同定の難易度を改善した.この縮約 FRF を用いてモード特性同定を行う手法を提案した.

2) FEM でモード特性の真值が得られる円筒シェルモデルを対象に, 提案手法を用いることでモード特性が高精 度に同定できることを検証した。

3) 実構造物の例として, 乗用車用タイヤのモード特性同定を行い, FRF に共振が明確に現れない中周波数帯域 においても，多数のモードを抽出できた．更に，同定結果に基づき，騒音低減のために対策すべき寄与の大きな モードを特定できることを示した.

これらのことから，提案する同定手法は，円筒シェル構造物のモード特性を効率的かつ高精度に同定するため の有効な方法であることを示すことができた.

\section{文献}

Dassault Systèmes Simulia, ABAQUS 6.11 analysis user's manual (2011), Rhode Island.

Efimtsov, B. M. and Lazarev, L. A., Sound pressure in cylindrical shells with regular orthogonal system of stiffeners excited by a random fields of forces, Journal of Sound and Vibration, Vol. 330, No. 15 (2011), pp. 3684-3697.

Fahy, F. and Gardonio, P., Sound and structural vibration, Second edition (2007), pp. 30-31, p. 391, Academic Press.

城戸一郎, モード解析の研究動向 : 自動車 NVH への適用を中心として, 日本機械学会 2010 年度年次大会講演資 料集(MECJ-10), Vol. 9 (2010), pp. 353-354.

松原真己, 小泉孝之, 辻内伸好, 平野裕也, 中村文哉, 接地時における夕イヤ半径方向振動解析, 自動車技術会春 季学術講演会前刷集, No. 20-12 (2012), pp. 1-4.

松岡久祥, 大熊政明, 安藤正登, 円筒形構造物に対する定常波離散化による新しい実験的モード特性同定法およ びタイヤのモデル化への適用，日本機械学会論文集 C 編, Vol. 68, No. 675 (2002), pp. 3322-3328.

Sandberg, U. and Ejsmont J. A., Tyre/road noise reference book (2002), p. 107, Informex.

Shih, C. Y., Tsuei, Y. G., Allemang, R. J. and Brown, D. L., Complex mode indication function and its applications to spatial domain parameter estimation, Proceedings of the 7th International Modal Analysis Conference (IMAC VII) (1989), pp. 
533-540.

Vercammen, S., Diaz, C. G., Kindt, P., Thiry, C., Middelberg, J. and Leyssens, J., Dynamic behavior of rolling tires under different operating conditions, Proceedings of the Internoise 2012 / ASME NCAD meeting (2012), pp. 301-307.

Waki, Y., Kozuki, K. and Heguri, H., Estimation of noise radiating parts of a tire using the wave finite element method, Proceedings of the Internoise 2011 (2011).

Williams, R., Crowley, J. and Vold, H., The multivariate mode indicator function in modal analysis, Proceedings of the 3rd International Modal Analysis Conference (IMAC III) (1985), pp. 66-70.

吉村卓也，長松昭男，モード解析に関する研究(第 9 報，多点加振に対応した最尤法に基づく曲線適合方法の提案 一その 1), 日本機械学会論文集 C 編, Vol. 56, No. 523 (1990), pp. 527-536.

\section{References}

Dassault Systèmes Simulia, ABAQUS 6.11 analysis user's manual (2011), Rhode Island.

Efimtsov, B. M. and Lazarev, L. A., Sound pressure in cylindrical shells with regular orthogonal system of stiffeners excited by a random fields of forces, Journal of Sound and Vibration, Vol. 330, No. 15 (2011), pp. 3684-3697.

Fahy, F. and Gardonio, P., Sound and structural vibration, Second edition (2007), pp. 30-31, p. 391, Academic Press.

Kido, I., Research trend of the modal analysis, Proceedings of the Mechanical Engineering Congress, 2010 Japan (MECJ-10), Vol. 9 (2010), pp. 353-354 (in Japanese).

Matsubara, M., Koizumi T., Tsujiuchi N., Hirano Y. and Nakamura, F., Tire vibration analysis for radial direction on a loaded condition, Proceedings of the Society of Automotive Engineers of Japan Spring Convention, No. 20-12 (2012), pp. 1-4 (in Japanese).

Matsuoka, H., Okuma M. and Ando M., A new experimental modal parameter estimation method for cylindrical structures by standing wave decomposition and application to tire modeling, Transactions of the Japan Society of Mechanical Engineers, Series C, Vol. 68, No. 675 (2002), pp. 3322-3328 (in Japanese).

Sandberg, U. and Ejsmont J. A., Tyre/road noise reference book (2002), p. 107, Informex.

Shih, C. Y., Tsuei, Y. G., Allemang, R. J. and Brown, D. L., Complex mode indication function and its applications to spatial domain parameter estimation, Proceedings of the 7th International Modal Analysis Conference (IMAC VII) (1989), pp. 533-540.

Vercammen, S., Diaz, C. G., Kindt, P., Thiry, C., Middelberg, J. and Leyssens, J., Dynamic behavior of rolling tires under different operating conditions, Proceedings of the Internoise 2012 / ASME NCAD meeting (2012), pp. 301-307.

Waki, Y., Kozuki, K. and Heguri, H., Estimation of noise radiating parts of a tire using the wave finite element method, Proceedings of the Internoise 2011 (2011).

Williams, R., Crowley, J. and Vold, H., The multivariate mode indicator function in modal analysis, Proceedings of the 3rd International Modal Analysis Conference (IMAC III) (1985), pp. 66-70.

Yoshimura, T. and Nagamatsu A., Research on modal analysis (9th report, proposition of multireference curve-fitting based on the maximum likelihood method - Part 1), Transactions of the Japan Society of Mechanical Engineers, Series C, Vol. 56, No. 523 (1990), pp. 527-536 (in Japanese). 